
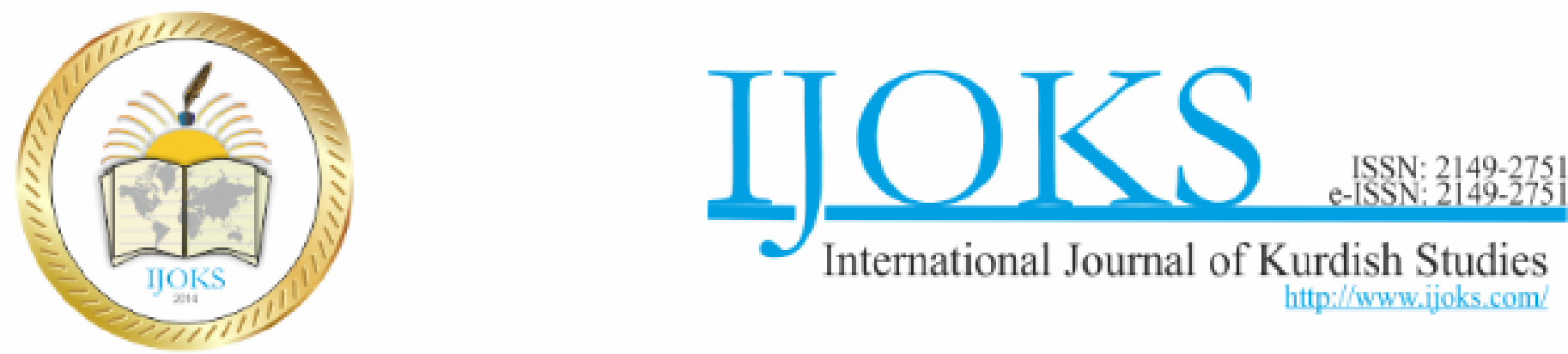

Article

\author{
International Journal of Kurdish Studies \\ 7 (2), pp. 253-286 \\ http://ijoks.com
}

\title{
The Kurdish Emirate of the Jawaniyya in the Region of Abbasid Baghdad (Eleventh and Twelfth Centuries)
}

Arafat $Y A Z^{1}$

Received: June 7, 2021

Reviewed: July 1, 2021

Accepted: July 24, 2021

\begin{abstract}
This study reveals the prevalence of Kurdish tribal states, political entities, in the vicinity of the Abbasid city of Baghdad. Through a presentation of the lives and contributions of leading Jawani personalities, it is shown that the Kurdish states contributed to the development of early Islam from both the political and religious aspects. The Jawani emirs were involved in most of the Baghdadi region's dealings with the Abbasid caliphate. They also had dealings with the Buwayhids, Ukaylids, Mazyadids, Annazids, Hasanvayhids, Marwanids and Seljuks. Sometimes, they formed alliances with these states, and sometimes they fought. The Jawani Emirate, one of the powers that determined the fate of the region until 557/ 1161-1162, lost their strong position after the Abbasid caliph expatriated the Mazyadids from al-Hillah. The present writer greatly relies on medieval Islamic sources, such as the scholars Masudi, Ibn al-Jawzi, Sibt Ibn al-Jawzi, İbn al-Athir, al-Dahabi and Ibn Khaldun.
\end{abstract}

Keywords: Kurdish Tribes, Jawani Emirate, Buwayhids, Baghdad Region, Early Islam.

\section{Recommended citation:}

Yaz, A. (2021). The Kurdish Emirate of the Jawaniyya in the Region of Abbasid Baghdad (Eleventh and Twelfth Centuries). International Journal of Kurdish Studies 7 (2), 253-286, DOI: https://doi.org/10.21600/ijoks.948821

\footnotetext{
${ }^{1}$ Ph.D. Turkish Republic, Ministry of Education. E-Mail: arafatyaz@gmail.com,
} 


\section{Introduction}

The Buwayhids (945-1055 CE), an Islamic dynasty of pronounced Iranian and Shiite character provided native rule in western Iran and in the Baghdadi region in the Abbasid and early Seljuq eras. In the second half of the $10^{\text {th }}$ century CE the Kurds put in an appearance. They established five states, largely north of Baghdad but to the south, the Kurdish emirate of the Jawani tribe. Here, we see how far-flung Kurdish populations had become. Moreover, when we look at the Jawanis we witness the Kurdish ability to transform their presence into a powerful political entity. The Jawanis appeared as a political power in 392/1001-1002, in the same period as the states of the Shaddadis were established in Armenia (951-1199) (Keleş, 2014: 270); the Rawwadis in Azerbaijan (954, surviving until 1129 or 1130); and the Hasanvayhis in Sulaymaniyah, Kermanshah, Nihavend and Azerbaijan (959) they were overcome by the Buwayhids in 1012; the Marwanis established themselves in Diyar Bakr Region in 978 later to be overcome by the Seljukian governor Ibn Jahir; and, the Annazis were established by Abul Fath Mohammed b. Annaz, the leader of Shazencan tribe (991). In about fifty years when the Seljuks had imposed their leadership on the Islamic world, surviving Kurdish emirates and states became dependent on the Seljuks and joined ranks with them in the struggle between the Seljuks and the Byzantiums and Fatimids. (Yaz, 2019: 139) The present study attempts to pinpoint the important Jawani personalities, and to investigate their political activities. It should be mentioned that this will be done for the most part in the light of the writings of early scholars such as Masudi, Ibn al-Jawzi, Sibt Ibn alJawzi, İbn al-Athir, al-Dahabi and Ibn Khaldun, who tend to record history in terms of battles and victorious rulers.

\section{The Relationship of Jaban al-Kurdi to the Jawani Kurds}

The name Jaban al-Kurdi, a companion of Prophet Mohammed, is suggestive of the name of the Jawani tribe. There are various narrations about the homeland of Jaban and his son, Abul Hakem Maymun, whose names are mentioned in Hadiths. They are thought to be Kurds. (al-Alusi, 1415: 13:257; al-Isbahani, 1998: 6:3073; Ibn Hajar al-Asqalani, 1326: 8:281, 10:394; Ibn al-Athir, 1994: 6:345) Although they are sometimes associated with "alȘardī," it seems more accurate to say "al-Bașrī," not "al-Ṣardī." Jaban is mentioned as the name of a village between the Yemeni villages and Wasit in eastern Iraq (al-Icli,1985: 2:306; al-Mizzi, 1980: 29:203, 30:15; al-Dahabi , 1992: 2:311; Ibn Hajar al-Asqalani, 1326: 10:388, 
1415, s. 1:540; Ibn Makula, 1990: 2:11) the name of an Armenian castle. (al-Katii, 4112: 1:304; al-Hamawi, 1977: 2:90; al-Suyuti, n.d.: 1:58; al-Maqrizi, 1997: 1:301) By way of observation, "Jaban" was the name of a Persian commander in the Battle of Namaraq (634 $\mathrm{CE}$ ) in the conflict between the Rashidun Caliphate under Caliph Omar and the Persian Sassanid Empire. (Ibn al-Athir, 1987: 2:284) The name Jaban might actually have been "Jawan". (Ibn Makula, 1990: 2:10) One may conclude that the "J" of Jaban underwent a phonetic change to become "Gavan" which means "cattle herder" in Kurdish. What makes this idea strong and acceptable is that the letters "G" and "V," present in Kurdish, do not exist in Arabic; they are accordingly coded as "J" and "B." However, we found no proof as a result of our investigations concerning any possible kinship between Jaban al-Kurdi and Jawanis. In fact, we have not come across any documents touching on this issue; the first mention we have on record about the Jawanis is in the middle of tenth century, which weakens our supposition.

\section{General Information about Jawani Kurds}

The first record of Jawani Kurds is in the work of Masudi, an Islamic geographer. (d. 346/956) Masudi mentioned the Jawanis (Jāwānīya) and Kurds together with tribes such as Bazenjan, Shuejan, Shazenjan, Neshshavere, Buzeykhan, Lorriyye, Jurkan, Baresian, Jalaliyah, Mistakan, Jabarika, Jurugan, Kikan, Majedan, Hazbaniyah and others. (al-Masudi, n.d.: 1:78; Minorsky, 1988:. 12) Relying on this record, Mustafa Jawad says that the Jawanis were the most famous Kurdish tribe of the fourth century. (Jawad, 1973: 8) We can accept this finding as accurate; it is entirely feasible as Jawani was the most famous Kurdish tribe of the time.

Masudi says that Kurds descended from Kurd b. Isfandyar b. Manucher inhabited Pars, Kirman, Sicistan, Khorasan, Ispahan and Jibal. (al-Masudi, n.d.: 1:78; Mehmed Emin Zeki, 1948: 421) On the other hand, after their appearance on the political scene, the Jawanis lived to the south of Baghdad; they were especially associated with al-Hillah, a city founded in 495/1101, and located one hundred kilometers to the south of Baghdad. (al-Subkî, 1413: 6:152) Al-Samani (d. 1167), who was contemporary with the Jawanis, refers to people with whom he had established relations as the Jūwān, people from Wasit whom he assumed were the same as the Jāwānīya. Wasit was a settlement in which Jawanis played a role. (al-Samani, 1962: 3:372-373) We think that although the tribe mentioned by al-Samani, who lived in the Resulayn area were called something similar to "Jawani" (Mohammed Emin Zeki, 1939: 
421); they actually belonged to a different tribe. (Ibn Khaldun, 200a: 3:570, 575; Ibn al-Athir, n.d., -a: 491; Sibt Ibn al-Jawzi, 2013: 19:96-97)

Returning to the subject of the name "Jawan," some records in the history books show that there was such a name among Arabs and even among Jews. On the other hand, Abul Buqa Hibatullah al-Hilli, who lived in the twelfth century, associated the Jawan tribe with Prophet Ismael. (al-Hillî, n.d.: 370) Burhanuddin al-Buqai (d. 1480) records that the name of one of the indigenous lands that Allah promised the Israelites during the lifetime of Prophet Moses was Ard al-Jawaniyyin. (the land of the Jawanis) (al-Buqai, n.d.: 1:425) al-Tabari, on the other hand, mentions a tribe called Banu Jawan (the descendants of Jawan) in the narrations on the ancestors and genealogy of Prophet Mohammed under the title of Ibn Adnan. (al-Tabari, 1968: 2:275)

Al-Hillah is the city which is identified with the Jawanis. It is reported that this city was established at the end of the fifth century by Barkyaruq b. Malikshah of Sayfuddawlah Sadaqah Ibn Mansur b. Dubays b. Ali b. Mazyad al-Asadi al-Mazyadi and Abbasid calif Mustazhir Billah due to their oath of allegiance. Measures were taken to attract merchants including the building of places of accommodation. It is said that al-Hillah, a city important in terms of trade being the route of pilgrimage convoys and river transportation, was founded by the Jawani tribe; they were allies together with the Mazyadids, and they settled there. (Jawad, 1973: 9-10) However, when the records were investigated, it could be seen that alHillah existed long before the mentioned date of 495. (al-Subki, 1413: 6: 152)

There is still a neighborhood in al-Hillah called Mahalla al-Akrad, (the Kurdish neighborhood) that is, the Kurdish district. Some say that "Akrad" designates the Karuda on the al-Hillah branch of the Euphrates, but the information in the sources shows that "Akrad" points to the Kurds. (Jawad, 1973: 9; http://mk.iq/view.php?id=437\&ids=3) The name "Akrad" surfaced at various times to show that the Kurds lived there. Ibn Battuta (d.770/1368-1369) says that there were Kurds in al-Hillah (Jawad, 1973: 10; Ibn Battuta, 2000:.1: 312), and Ibn Unba (d.828/1424) -1425) mentioned Mahalla al-Akrad (Jawad, 1973: 10-11. Ibn Unbe, 1961: 147), and al-Suyuti (1505) indicated that the Jawani Kurdish tribe inhabited a-Hillah, (al-Suyuti, n.d.: 1:59) al-Zabidi (d. 1791) said that Jawan was a Kurdish tribe inhabiting in al-Hillah. (al-Zabidi, 2001: 34: 387) According to these sources, the Jawanis have maintained a presence in al-Hillah until recently. 
The Jawanis, who belonged to Shāfi 'ī religious sect in their early period, became Shiites when they drew close to the Mazyadids, who were their allies and relatives. When it comes to the time of Ibn Battuta (d. 767 / 1365-1366), we see that the people of al-Hillah were Shiites. In his travel book (Seyahatname/Travelogue), Ibn Battuta states that all the inhabitants of al-Hillah were affliliated with the Imamiyyah Isna Ashariyah, but that there were two factions, known as Akrad (the Kurds) and Ahl al-Jāma'īn. The two factions fought continuously. (Jawad, 1973: 10; Ibn Battuta, 2000: 1:312)

Starting from the year 392, which we accept as the date of the emirate's establishment, the Jawani emirs and their political activities were as follows:

\section{Varrām b. Mohammed (d. 403)}

The first known record of the Jawani Kurds in the political arena is in the work of alRudrawari. There has been no information about them until this date. They are present in records from when they took sides in wars and historians mentioned them. Contrary to Ibn alAthir, the first incident in which al-Rudrawari mentions the Jawani Kurds is when they were an important tribe with military power and acted together with the Annazids. Although his name is not given, Varrām $b$. Mohammed must have been the leader of this tribe at that time. ${ }^{2}$ In the war, which took place in 392 (1002), Abu Jafer al-Hajjaj, one of the Buwayhid commanders, confronted the Ukaylid / Mazyadid alliance. In the war, the Emir of Annazid, Abul Fath Mohammed, who was under the command of the Jawani and Shazenjaniyyah tribes with two hundred horsemen, played a key role. Abu Jafer marched on the camps of the Mazyadids, and the Jawanis, who deserted the Buwayhids and joined Abul Fath, became rich with booty they obtained along with the Shazenjan Kurds. (al-Rudrawari, 2001: 7: 488-489; Ibn al-Athir, n.d., -b: 9: 141; Zarar Sadiq Tavfiq, n.d.: 56)

The name of Varrām b. Mohammed is mentioned in the siege of Baghdad. Instead of Abu Jafar al-Hajjaj b. Hormuz, who was Iraq regent of Buwayhid ruler, in 393 / 1002-1003, Bahauddawlah Amiduljuyus (عميد الجيوش) Abu Ali b. Abu Jafar Ustaz Hormuz was appointed, and the tribes of Banu Ukaylid, Haface and Banu Asad took part in the war that broke out between them. (Ibn Khaldun, 2000a: 4: 690) When it came to the year 397/1006-1007, Abu

\footnotetext{
${ }^{2}$ Varrām is mentioned as the name of a town or village with people close to the Rey, who were Shiites. Ibn alFaqih and Ibn Hurdazbeh mentioned Varrāmīn in context of the Mosul climate. Ibn al-Jawzi speaks of Banū Varrām. (Burhanuddin al-Harazmi, nd: 1: 483; al-Katii, 4112:.3: 1431; al-Hamawi, 1977:.5: 370; al-Samani, 1962,: 13: 306; Al-Suyuti, nd: 1: 273; Ibn Hurdazbih, 1889: 1: 94; Ibn al-Jawzi, 1992: 15: 316; Ibn al-Faqîh, 1996:1: 179)
} 
Jafer al-Hajjaj besieged Baghdad with a large army with the support of the Kurdish Hasanvayhid emir, Badr b. Hasanvayhid. When Amiduljuyus assigned Abul Fath b. Annazid, the enemy of Badr b. Hasanvayhid to keep Tariqu Khorasan, ${ }^{3}$ and this led Hindi b. Sadi, Abu Isa Shazi b. Mohammed, the Jawani leader Varrām b. Mohammed and some other emirs to join the ranks of Abu Jafer al-Hajjaj. While Amiduljuyus was far away near Bahauddawlah to fight against Abul Abbas, an army of 10 thousand soldiers besieged Baghdad for a month, and Abul Fath Annazid and Turkish soldiers protected Baghdad. When the news of the victory of Amiduljuyus and Bahauddawlah was heard, Abu Jafar and his followers were discouraged and dispersed. Abu Jafar later smoothed his relationship with Bahauddawlah through peace. (Jawad, 1973: 12; Ibn Khaldun, 2000a: 4: 690; Ibn al-Athir, n.d.-b: 9: 159, 1987: 7: 546) In 392, The Kurds, who were with Abul Fath b. Annaz this time, took side with another Kurdish leader, Badr b Hasanvayh, who was his enemy.

In 403/1012-1013, Varrām b. Mohammed passed away and his son Abul Fath b. Varrām replaced him. Ibnu al-Jawzi, referring to the events of the year 403, states that Varrām al-Turkî passed away and his son Abul Fath was replaced by him. Since there is no such person as al-Turki, this situation should be regarded as a mistake made by Ibnu al-Jawzi or the copyis. (Ibnu al-Jawzi, 1992: 15:97; Zarar Sadiq Tavfiq, nd.: 57)

\section{Abul Fath b. Varrām (403-455)}

Abul Fath, who succeeded his father Varrām b. Mohammed after his death, is the most well-known ruler of the Jawanis. Although he served as the emir of his emirate for more than fifty years, we do not have much information about him except historical events. We first see him on the side of the Mazyadids in the war between the Dubaysid and the Mazyadid. When Abul Hasan's brother Abul Ganaim b. Mazyad was murdered by the Dubaysid in Muharrem 405 (July-August 1014), a war broke out between Abul Hasan Ali b. Mazyad al-Asadi and the Dubaysid cosisting of Mudar, Nahban, Hassan and Tarrad. The Mazyadids, who want to take revenge, joined Arabs together with Shazenjan, Jawanis, and other Kurds; and the Mazyadids were victorious in the war that took place between them. Nahban and Hassan, two sons of Dubays, were killed and their properties were seized, and those who escaped and survived were caught in al-Howayz. (Ibn al-Athir, n.d.-b: 9: 199,

\footnotetext{
${ }^{3}$ It was called the land of the present-day city of Diyala. (Zarar Sadiq Tavfîq, nd.: 57)
} 
1987: 7: 597-598) After this period, the alliance between the Jawanis and the Mazyadids continued for a long time and strengthened with kinship relations.

In fact, there were frequent clashes both tribes in the throne fights of the Buwayhids and among the local governments. Although it does not seem very possible for the Jawanis to stand aside in these conflicts due to their inhabitants to be very close to Baghdad, most of the time, their names were not mentioned among the parties. Local governments such as Mazyadids, Dubaysids, Annazids, Ukaylids, and Hasanvayhids who were active in the region during these wars could not remain neutral even if they wanted to. (Ibn al-Athir, n.d.-a: 9: 291) Although we think that they took part in some struggles, these events were not mentioned since the names of the Jawanis were not mentioned.

In another case involving Abul Fath Varrām, the Arabs plundered the lands of Nehr al-Malik and Baghdad in 421 (1030) with the order of the Ukaylid leader Karvash. Due to the burning of many villages and the plundering of their properties, the ruler of Buwayhid came to wrath and marched on Karvash. Commander Abul Vafa and with him Abul Fath b. Varrām went over Karvash and reached Sundīya on 6 Safar. (Sibt Ibn al-Jawzi, 2013: 18: 433) Ibn alAthir, while describing the year 431, described the events that took place between Karvash and Jalaluddawlah, but what he told did not correspond to what Sibt said. (Ibn al-Athir, n.d.b: 9: 374)

While the Jawani leaders were sometimes enemies with the Buwayhid commanders, sometimes they got very close with the Buwayhid rulers. Sibt Ibn al-Jawzi stated that Arslan Basasiri, one of the Buwayhid commanders, wanted to march on Abul Fath b. Varrām because of his affairs in al-Nahravanat, but Caliph al-Kaim prevented this. (Sibt Ibn al-Jawzi, 2013: 18: 436) On the other hand, it is seen that Abul Fath b. Varrām went to help the ruler of Buwayhid, who was in a difficult situation. Turks, who took their tents out of the city and plundered some places, revolted against Jalaluddevle on Zilkada 431 (1040) and did not allow Jalaluddevle to leave the city when the persuasion efforts failed. The ruler of Buwayhid, Jalaluddevle b. Bahauddawlah b Adududdawlah, who was in a difficult situation, asked for help from Abul Fath b. Varrām and Abul Favaris b. Sadi and Dubays b. Ali alMazyadid. In these events, the people in Baghdad suffered when the plunder turned into famine. (Jawad, 1973: 13; al-Dahabi, 1993: 29: 319; Ibn Taghribardi, 1935: 5:31; Ibn alJawzi, 1992: 15: 273; Ibn al-Athir, n.d.-b: 9: 360; Sibt Ibn al-Jawzi, 2013: 19: 436)

In the records of 432, it is seen that the Jawanis were involved in the internal affairs of the Annazids. While Husamuddawlah Abu Shavk b. Annaz and his brother Abul Majid alMuhalhil b. Mohammed b. Annaz were fighting for Dakuka (Dakuk), his brothers Surhab b. 
Mohammed b. Annaz took some parts of Abu Shavk and looted there and made an agreement with the Kurds of Abul Fath and Jawanis against him. Abu Shavk personally took the city of Dakuka by besieging it, but came back with the fear of losing al-Bandanijin and Hulwan and asked for help from Jalaluddevle and received military support from him. (Jawad, 1973: 13; Ibn al-Athir, n.d.-b: 9: 375, 1987: 8:21)

In 433 (1041), the name of Abul Fath b. Varrām is mentioned in the uprising of the Ghilmans (Ghilmānī) in Wasit against Malik al-Aziz and the events that followed. Ghilman s wanted Malik al-Aziz's Vizier Abul Fadl b. Tayyib to be handed over to them, but their requests were not accepted. Malik al-Aziz went to Numaniyah and requested help from his father Jalaluddevle and Dubays to expel the Ghilman s from Wasit. The vizier was arrested and sent to Wasit on the advice of his father. When Malik al-Aziz went to Wasit, the Turks plundered people's houses and killed some of them. Jalaluddevle, together with Basasiri, moved from Baghdad to Wasit on 7 Safar 433 to fix the situation. Basasiri and with a group Ghilmans went to the region of Badaraya and the area of his enemy, Abul Fath Varrām. Basasiri tried to kill him many times, but the caliph and Malik prevented him. Malik arrived in Wasit in Rabī' al-Awwal. In this incident, Dubays and Malik intervened in the solution of Ibn Varrām's problem. (Sibt Ibn al-Jawzi, 2013: 18: 440-441)

The long-lasting emirate of Abul Fath b. Varrām coincided with the establishment of the Seljuks and their being an effective power in the Islamic world. After 432 (1040-1041), the Oghuzs entered Pars, Azerbaijan, Diyar Bakr, Diyar Rabia and caused chaos there. The Oghuzs fought with the Kurds around Azerbaijan and Hakkari then marching down, fought with the Kurds and Arabs in Diyar Bakr and Mosul in the same way and captured Mosul. The Ukaylid emir of Mosul, Karvash, sought help from the Buwayhids, Mazyadids and other Arabs and Kurds. After the ruler of Buwayhids, Jalaluddevle, stood back due to the opposition of the Turks in his army, Annazid emir Abu Shavk and Jawani Emir Ibn Varrām marched on Mosul immediately and defeated the Oghuzs. (Jawad, 1973: 12; Ibn al-Athir, n.d.-b: 9: 299-301) Local governments came together and defended themselves against the Oghuzs, who threatened the rulers in Azerbaijan, Diyar Bakr, Pars and Iraq and carried out pillaging and plundering activities and terrorized the places they entered. The activities of the Oghuzs, who escaped from Ibrahim Yinal at first and entered these lands and caused a great indignation, later continued under the control of the Seljuks. The struggles between and within the local powers in the vast geography and the incompetence of the Buwayhids, who were their protectors, caused them to be unable to resist against the Seljuks. In a short time, the areas under the control of the Buwayhids began to fall under the control of the Seljuks. In 
the first place, local governments, who tried to protect their homeland together with the Buwayhids, realized that it was not possible to resist to the Seljuks. (Ibn Khaldun, 2000a: 4: 695; Ibn al-Athir, n.d.-b: 9: 394, 399, 400, 402-404)

While the Seljuks tried to attract the local rulers to their side and break the Buwayhid's influence, they also carried out actions to benefit from the internal conflicts that took place between them. In 438/1046, besides the Seljuks, the Jawanis also took sides in the struggle for the throne and land of the Annazid Kurds. In the fight between the Annazid emirs, Sadi b. Abu Shavk and his uncle Muhalhil, he took the side of Ibrahim Yinal and gave khutbahs on the name of him in order to consolidate his power. Resisting his uncle with the help of Oghuzs and Jawani emir Abul Fath b. Varrām, Sadi took al-Bandanijin and transferred the city to Abul Fath b. Varrām as iqta. Sadi and Abul Fath went to besiege another Annazid emir, Surhab b. Mohammed b. Annaz, in Dazdiluyah Castle. When Sadi and Abul Fath entered a narrow strait without any precautions, they were attacked by Surhab and captured. (Jawad, 1973: 13; Ibn Khaldun, 2000a: 4: 697; Ibnul-Athir, n.d.-b: 9: 405-407) According to the problematic expression of Ibn al-Jawzi, ${ }^{4}$ in this case, Abul Fath b. Varrām, his son and brother, Halid b. Omar and Sadi b. Faris b. Annan (Annaz) were captured, and Varrām and his two sons were killed. (Ibn al-Jawzi, 1992: 15: 306) However, the fact that Abul Fath b. Varrām was alive until 455 shows that Ibn al-Jawzi was wrong. Perhaps those who claim that the person killed was another Jawani leader were right. (Zarar Sadiq Tavfiq, n.d.: 59)

From 434 to 437, there were fierce struggles between the Oghuzs and the Kurds for the domination of the castles of Hulvan, Karmisin, Hanikayn, Mayedesht, al-Bandanijin, Dezdiluyah, al-Sirevan, which were under the control of Annazids and Jazvekan, the Shazanciyah Kurds. (Ibn al-Athir, n.d.-b: 9: 391-411) At the end of 439, that is, at the end of 1047, the Jawani Kurds took part in these intense clashes that took place nearby their settlements. It is seen that Ibrahim Yinal captured the places that were in the hands of Annazids and Hasanvayhids on this date. Kinkavar, Kalakan, Dazdaluyah Castles were besieged by the Oghuzs and al-Bandanijin, which was in the hands of Abul Fath b. Varrām, was wanted to be captured (November-December 1047). When the Oghuzs went over Abul Fath b. Varrām, he first fled, but then he turned back and fought against the Oghuzs for the possibility of his nomad camp being plundered. Abul Fath b. Varrām, who killed and

\footnotetext{
${ }^{4}$ The phrase written as (وقتل راما و ابنيه وصلبهم) should be like (وقتل وراما و ابنيه وصلبهم).
} 
captured many of the Oghuzs, asked Baghdad for help, thinking that the danger was not over, but the Buwayhids did not help him because they were afraid. The Jawanis, who settled in the west bank of the Tigris as a precaution, were abandoned by the Buwayhids.

After this incident, we come across the names of Abu Dulaf al-Qasim b. Mohammed al-Jawani and his son Ali b. Qasim al-Kurdi in the records. Abu Dulaf must be an emir from the family under the command of Abul Fath b. Varrām. We see him in the war fought against the Oghuzs in 1048. As a result of the attacks of the Oghuzs at the beginning of 1048, alDastkara, Bajisra, al-Haruniyyah, Kasr Sabur and all the towns and villages in that region were plundered. Ibrahim Yinal came to Tikrit, captured the city and returned to Hamadan. When the Oghuzs, who took al-Bandanijin and settled there, which was in the hands of the Jawanis, walked to Balad al-Rūz, Abu Dulaf al-Qasim b. Mohammed al-Jawani came up against them in Nahr al-Salil. Abu Dulaf defeated the Oghuzs in the tough battle fought here and seized their properties. Some of the Oghuzs attacked and devastated the town of Ali b. alQasim al-Kurdi, who was the son of Abu Dulaf, in Dhu al-Hijjah (May-June 1048). They killed many people in the area and looted their properties. (Jawad, 1973: 15; Ibn Khaldun, 2000a: 4: 698; Ibn al-Athir, n.d.-b: 9: 409-411)

Sibt Ibn al-Jawzi, who tells about the death of the vizier of Buwayhid Abu Kalijar, Mohammed b. Jafar Abu Saade in 440 / 1048-1049, gives us the name of a castle that we do not know to be of Jawanis. Sibt says that Abu Kalijar sent the body of the deceased vizier to the Banu Varrām Castle in Hendef. (Sibt Ibn al-Jawzi, 2013: 18: 433)

As the days passed, the local rulers gave up mentioning the names of the Buwayhids in the khutbahs and engraving their names on the coins; and they declared their loyalty to the Seljuks one by one. In 440 / 1048-1049, it is seen that the Annazid leader Sadi b Abu Shavk marched on al-Dastkara, clashed with the Baghdad authority and defeated the two forces sent by them. Sadi's soldiers, who plundered the places they had captured, had khutbahs read on behalf of Ibrahim Yinal of the Seljuks. (Ibn Khaldun, 2000a: 4: 698-699; Ibn al-Athir, n.d.-a: 9: 418-419) The Kurdish Marwanids, who were in power in Diyar Bakr, had the khutbah read on behalf of the Seljuks in the early period in 441 with the request of Togrul Bey (Ibn alAthir, n.d.-a: 9: 422). In 442, Abu Shavk's brother Muhalhil b. Mohammed b. Annazid went to Togrul Bey, and had his legitimacy recognised by him and let his brother Surhab be released. The Seljuks entrusted al-Ravedeyn to Sadi b. Abu Shavk in return for his devotion. (Ibn al-Athir, n.d.-a: 9: 433)

While the local rulers sided with the Seljuks, the Jawanis were still standing against them. By the year 444/1053, the Jawanis were still opposing the Seljuks and their allies. In 
the year mentioned above, the reason for the incidents that took place was that Sadi b. Abu Shavk wanted to control a larger area after reaching an agreement with the Seljuks. However, one of the people who had to be defeated was Abu Dulaf, the leader of the Jawanis. Sadi, the slave of the Seljuks, took an army from Sultan Togrul Bey and entered Iraq in the month of Zū al-Qa'ida in 444 and stayed in Mayadesht. Meanwhile, a cavalry unit from the Oghuz marched on Abu Dulaf. When Abu Dulaf escaped from the battle field, Sadi was able to seize merely his property. ${ }^{5}$ Sa'di's troops advanced as far as Numaniyah. Here, they committed the crimes of looting, killing and raping by acting extreme actions. Sadi fought against his uncle Muhalhil and defeated him and took him prisoner with his son. These successes of Sadi created fear and anxiety in Baghdad. Baghdad Buwayhid ruler al-Malik al-Rahim wanted to embark on a campaign against Abul Agar Dubays b. Mazyad al-Asadi and Sadi, but he could not do anything. In addition to being weakened militarily, the Buwayhids could not find a solution to attract local governments to their side politically. (Jawad, 1973: 15; Ibn al-Athir, n.d.-b: 9: 447, 1987: 8: 107) Finally, in 447/1055, Togrul Bey himself marched on Baghdad and ended the rule of Buwayhids. (Ibn al-Athir, n.d.-b: 9: 462) After conquering Baghdad, Togrul Bey reestablished the balances and arranged the iqtas, in other words, the positions of the emirs.

After the Seljuks conquered Baghdad, they further increased their activities in and around al-Jazeera. The emirs in the region saw the Seljuks as a threat to their power. In addition, the looting and plundering activities of the Oghuzs frightened them, causing them to pay a heavy price in every aspect due to their sectarian preferences. The hostility between the Abbasid vizier Ibn Muslim and the military governor of Baghdad Aslan Basasiri determined the direction of a series of events from 448 to 451 . Basasiri blamed Muslim due to his connection with Togrul Bey; on the other hand, Ibn Muslim blamed Basasiri for his connection with the Fatimids. After Togrul Bey conquered Baghdad, Basasiri revolted against him. It is seen that the emirs in the region were in fact on the side of the Basasiri and against the Seljuks. When they felt obliged, they paid allegiance to Togrul Bey; and when the conditions changed, they turned against him. Of course, there were exceptions to this situation, for example, the Kurdish leader Hazaresb was one of those who stood firmly loyal to Togrul Bey (Jawad, 1973:14-15; Merçil, 1992: 528).

\footnotetext{
${ }^{5}$ Ibn Khaldun says that this event happened in the year 446. (Ibn Khaldun, 2000a, :4: 698)
} 
Arslan Basasiri came to the fore by revolting against Togrul Bey after he conquered Baghdad. The hostility between the Abbasid vizier Ibn Muslim and Basasiri, who took shelter in Al-Hillah and then in Rahba, led him to seek help from the Fatimids. The Fatimids were fighting resolutely to establish their own political purpose and sovereignty in and around Syria, Iraq. Taking this opportunity, they assigned Dai al-Duat Hibatullah al-Shirazi to carry out the diplomatic war against the Seljuks in Iraq and Syria. As a result of the environment and the clever moves of the al-Shirazi, alliances were formed against the Seljuks. The fact that Egyptian Fatimid caliph al-Mustansir sent robes of honour from Egypt to be given to alBasasiri, Nuruddawlah Dubays b. Mazyad, Jabir b. Nashib, Quraysh's brother Muqbil b. Badran, Abul Fath b. Varrām, Nusayr b. Omar, Abul Hasan b. Abdurrahim and Mohammed b. Hammad shows the fruits of his efforts. (Ibn Khaldun, 2000a: 3: 570)

We also see the Jawani leader Abul Fath b. Varrām in these stages of alliance and struggle. Abul Fath b Varrām also took part in the block opposite the Seljuks. However, he obeyed the Seljuks like the other emirs when he was in a difficult situation. In the first recording we came across in this process, it is seen that while Basasiri was at Rahba, Ibn Varrām joined him, setting out from Baghdad with Muqbil b. Badran. The alliance between Basasiri and the emirs was broken in a short time because as Ibn al-Athir says, Quraysh b. Badran also joined Basasiri. However, Sibt notes that when he went to Rahba to join Basasiri, Quraysh and Nuruddawlah b. Mazyad paid allegiance to Togrul Bey, fearing that their country would be plundered. It is obvious that Quraysh and Dubays first became a party to Basasiri and then to Togrul Bey (Ibn al-Athir, n.d.-a: 9: 474; Sibt Ibn al-Jawzi, 2013: 18: 499,505). Contest between emirs also dictated the course of the alliances. For example: During the event we have mentioned (Safar 448/April-May 1056), Muqbil b Badran's struggle with his brother Quraysh was effective in taking Basasiri's side. (Sibt Ibn al-Jawzi, 2013: 18: 499)

While the struggle between the two sides was going on, it is seen that on 9 Shaban 448 (22 October 1056) Ibn Varrām was still together with Basasiri, Dubays, Muqbil and Ibn Hafajah, who opposed the Seljuks. Qutalmish and his army marched to Wasit to fight Ibn Fasanjis, but when Quraysh informed that Basasiri and his allies were going from Habur to Mosul, the army was recalled. The Abbasid caliph tried to control the situation by writing a letter to the people of Wasit. (Sibt Ibn al-Jawzi, 2013: 18: 506)

While the struggle was continuing, in Shawwal 448, Basasiri, Dubays, Muqbil, Ibn Varrām, Arabs, Gulams and Kurds fought with Quraysh b. Badran and Hajib al-Kabir in the Battle of Sinjar. While Qutalmish hardly saved his life in this war, Hajib al-Kabir was killed. 
Dubays tried to persuade Quraysh and attract them to their ranks, but failed. The allies, to which Ibn Varrām was a part and led by Basasiri, had triumphed against the Seljuks and the Abbasid caliphate (Sibt Ibn al-Jawzi, 2013: 18: 507). Ibn al-Athir says that the robes of honour sent by the Fatimid caliph of Egypt, al-Mustansir, were sent them after the victory of Sinjar. On the other hand, Ibn Khaldun says that the people who were sent robes of honour were on the battlefield (Ibn Khaldun, 2000a: 3: 570; Ibn al-Athir, n.d.-a: 9: 474). This victory paved the way for Basasiri to conquer Mosul, but the Quraysh and Dubays changed sides (Dhu al-Qadah 448), and wore the Egyptian robes of honour. After Togrul Bey took action and captured Tiktrit (7 Dhu al-Hijja 448), he marched on Mosul, but the people of Basasiri and Mosul left the city because of him. (Sibt Ibn al-Jawzi, 2013: 18: 508-510)

When Togrul Bey marched on Nusaybin after Mosul, Kurdish Emir Hazaresb, the Sultan's commander, ambushed and defeated the Arabs and put the Basasiri alliance in a difficult position. This defeat caused Nuruddawlah and Quraysh, who took side with Basasiri, to ask for forgiveness by means of Hazaresb from Togrul Bey. Dubays and Quraysh, two important leaders of the opposition, asked Togrul Bey to assign Abul Fath b. Varrām to mediate. Firstly, Abul Fath b. Varrām and then through the mediation of Hazaresb, the emirs took the side of Togrul Bey. Togrul Bey pardoned Dubays and Quraysh and reinstated their homeland to them as iqtas. Abul Fath b. Varrām and his notables were sent back by wearing robes of honour. (Ibn Khaldun, 2000a: 3: 572; Ibn al-Athir, n.d.-a: 9: 476-477; Sibt Ibn alJawzi, 2013: 19: 10-11) This is the first event in which the Jawanis were on the side of the Seljuks.

After entering the Sultan's command, it is seen that Quraysh and Ibn Mazyad wrote a letter to Hazaresb in Jumadi al-ahir 449 (1057), complaining about the plundering of their lands and non-compliance with the treaty made. (Sibt Ibn al-Jawzi, 2013: 19:15) While Dubays was returning to his country in the month of Shaban, Quraysh rebelled and went to Rahba to the side of Basasiri. Quraysh was telling Dubays that his country was destroyed, and that the sultan was in his land and he was not sure of his intentions. (Sibt Ibn al-Jawzi, 2013: 19:16)

Togrul Bey returned to Baghdad after handing over Mosul and its surroundings to his brother Ibrahim Yinal. The Caliph organized a general reception ceremony on 25 Dhu alQadah 449 (23 January 1058); and the great commanders of the sultan attended this ceremony. (Ibn al-Athir, n.d.-a: 9: 480-481) Sibt Ibn al-Jawzi says that in the middle of Shawwal, Badran b. Dubays and Abul Fath b. Varrām went to Baghdad and Ibn Varrām was reprimanded by Rais al-Ruasa (the President of the Presidents) for his inclination to Basasiri. 
When Togrul Bey returned at the end of the month, Badran, Ibn Varrām and Rais al-Ruasa met him. When they came together with the Sultan, the Sultan asked them about the circumstances of Nuruddawlah Dubays and Quraysh. On the date of 25 Dhu al-Qadahin 449, the Sultan went to the caliph and the caliph organized a big ceremony for him. Badran, Ibn Varrām, Amid of Iraq and many state officials were present at this ceremony (Sibt Ibn alJawzi, 2013: 19:20). Ibn al-Athir says that in the same year, Dubays b. Ali b. Mazyad and Mahmud b. Ahram al-Hafaji settled the relations with Togrul Bey and returned to their country. (Ibn al-Athir, n.d.-a: 9: 483)

In 450 Hygria, Basasiri and Quraysh b. Badran marched on Mosul and captured the city. Sultan Togrul Bey immediately marched on Mosul and Basasiri fled away from Mosul. While the Sultan was heading towards Nusaybin to follow them, Ibrahim Yinal arrived there on the 26 of Ramadan 450 (16 November 1058), intending to take Hamadan. Yinal exchanged letters with the Fatimids and opposed Togrul Bey and wanted to be the ruler. Togrul Bey left Basasiri and went to Hamadan to fight with Ibrahim Yinal. (Ibn al-Jawzi, 1992: 16: 30-31; Ibn al-Athir, n.d.-a: 9: 484; Sibt Ibn al Jawzi, 2013: 19:60) Togrul Bey went to Hamadan on 15 Ramadan 450 (5 November 1058) and asked for help from Baghdad caliph and Dubays b. Mazyad but could not get the assistance he wanted. Taking advantage of Togrul Bey's departure, Basasiri arrived in Baghdad on 8 Dhu al-Qadah 450 (27 December 1058) and gave a khutbah on behalf of the Fatimid caliph al-Mustansir Billah. Rais ar-Ruasa was killed and the Caliph took refuge in Quraysh b. Badran and the caliphate palace was plundered for days. (Ibn al-Athir, n.d.-a: 9: 485-486; Sibt Ibn al-Jawzi, 2013: 19:56, 61, 6465) When the conditions changed in favour of Basasiri, it is seen that Dubays b. Mazyad changed sides and came to Baghdad. (Sibt Ibn al-Jawzi, 2013: 19:71)

In Jumada al-awal 451 (1059), it is seen that Basasiri was moving from Wasit to Ahvaz, with Dubays, Sadaqah b. Mansur and Abul Fath b. Verram accompanying him (Sibt Ibn al Jawzi, 2013: 19:84). After 19 Jumada al-Ahir 451, Basasiri approached Ahvaz, but had to turn back. In Mamuniye, Basasiri and Hazaresb came face to face. Basasiri offered Hazaresb to read the khutbah on behalf of the Fatimids and have the coin cut on behalf of them, but Hazaresb refused to accept it. After Dhu al-Hijjah, a clash broke out between them and in the meantime, the news of Togrul Bey's victory came. When Basasiri saw that the situation deteriorated, he quickly returned to Wasit and planned to gather soldiers and go against Hazaresb. However, the emirs such as Dubays, Abul Fath b. Varrām and others, who were with him, had returned to their homeland. Basasiri wrote a letter to Quraysh and 
complained that Dubays and Ibn Varrām had left him alone. (Ibn al-Jawzi, 1992: 16:45; Ibn al-Athir, n.d.-a, s. 9:488; Sibt Ibn al-Jawzi, 2013: 19:85-86)

Although Togrul Bey was militarily weaker than Ibrahim Yinal, he defeated him and killed him on 9 Jumada al-Ahir 451. Togrul Bey wanted to come to terms with Basasiri in the first place, but when he received a negative answer, he marched on Iraq (Ibn al-Athir, n.d.-a: 489; Sibt Ibn al-Jawzi, 2013: 19:82). The caliph, who was removed from Baghdad, came back to Baghdad on 25 Dhu al-Qadah 451 (2 January 1060), and Togrul Bey pursued Basasiri after he was safe in Baghdad. Marching on Kufa, Humartekin plundered the city on 8 Dhu alHijjah 451 (15 January 1060), and Basasiri and Dubays b. Mazyad were not aware of the situation until their enemies approached them. The Arabs under the command of Nuruddawlah Dubays left the battlefield; and when Nuruddawlah could not prevent them, he himself left Basasiri as well. When the army under the command of Togrul Bey attacked, according to Sibt's statement, al-Hillah's Kurdish Emir Abul Fath b. Varrām, three sons of Nuruddawlah Dubays, Mansur, Badran and Hammad, were captured and Basasiri was killed. (Ibn Khaldun, 2000a: 3:575; Ibn al-Athir, n.d.-a: 491; Sibt Ibn al-Jawzi, 2013: 19:96-97; Jawad, 1973: 16 -17; Al-Dahabi, 1993: 30:272) In the history of Ibn Abul-Hayja, he says that in the war that took place in 451, Ibn Mazyad was defeated and one of the prominent Kurds, Abul Fath b. Varrām was taken prisoner and was released by Sultan Togrul Bey's stepson, Anushirvan. (Ibn Abul Hayca, 1993: 110; Zarar Sadiq Tavfiq, n.d.: 61) After the collapse of Basasiri and Fatimid bloc, Abul Fath b. Varrām, surrendered to the Seljuks and acted together with them.

On 17 Safar 452 (23 March 1060), we see Abul Fath b. Varrām at a ceremony held in Baghdad with the participation of important emirs. On the way from Wasit to Baghdad, Togrul Bey accompanied by Abul Fath b. Varrām, as well as Hazaresb b. Bengir b. Iyad, Dubays b. Mazyad, Abu Ali b. Malik Abu Kalijar, Sadaqah b. Mansur b. al-Husayn and other leaders. The Caliph presented Togrul Bey many gifts. Afterwards, Togrul Bey held a banquet and invited the emirs and gave them a robe of honour each. (Ibn al-Athir, n.d.-a: 10:28; Sibt Ibn al-Jawzi, 2013: 19:103) While describing the event, Ibn Taghribardi refers to the Jawani leader as an emir. (Ibn Taghribardi, 1935: 5:67)

When Sultan Togrul Bey died on 8 Ramadan 455 (September 4, 1063), his vizier alKunduri went to his place. The Abbasid vizier, Fahruddawlah Ibn Jahir, expressed his condolences for the death of Togrul Bey in Baghdad on 26 Ramadan and set up a condolences tent. After Togrul Bey's death, the caliph al-Qaim invited the owner of Mosul, Sherefuddawlah Muslim b. Qurayş, Nuruddawlah Dubays b. Mazyad, the owner of Ahvaz 
Hazaresb, Abul Fath b. Varrām, his brother Abu Najm b. Varrām and Badr b. Muhalhil. The reason for this is that the Arabs began to plunder around Baghdad, and the caliph must have wanted to prevent the breakdown of the order for fear of a conflict. For this purpose, he brought them together. However, at this time, the chief of Jawanis Kurds, Abul Fath b. Varrām, died in Baghdad and his coffin was taken to Jarjaraya (Ard al-Kut). It seems that no agreement must not have come out of this meeting because Sharafuddawlah Muslim left Baghdad and plundered its surroundings. For this reason, Nuruddawlah Dubays b. Mazyad, Banu Varrām and Banu Hafaje took action to fight him. After the struggle between them, peace was established by sending robe of honour to him from the caliphate council. (Jawad, 1973: 18; Ibn Khaldun, 2000b: 3:578; Ibn al-Athir, n.d.-b: 10:41-42, 1987: 8:184; Sibt Ibn al-Jawzi, 2013: 19: 151-152,154-156) Those invited to Baghdad are the leaders of the states and emirates that dominate the region. The fact that Abul Fath and Abu Najm b. Varrām were among them indicates that they had a say in determining the fate of the region. Since Abul Fath b. Varrām passed away in 455, his brother Sayfuddawlah Abu Najm took his place.

\section{Sayfuddawlah Abu Najm Badran b. Varrām al Kurdi (d. 471)}

The reason why Abu Najm's name was written in the first record in 455 is probably due to the death of his elder brother, Abul Fath b. Varrām, in Baghdad. The fact that two of them were summoned to Baghdad together shows that they were both important emirs. It can be interpreted as they were emirs of different regions. There is no information about when Abu Najm was born and his previous life. In addition, his nickname "Sayfuddawlah" shows that he was an emir and was recognized by the Abbasid Caliphate. Because the nicknames ending with "dawlah" were given to the emirs who dominated a region. In the light of this information, we can say more confidently that the Jawanis had the authority during the time of Sayfuddawlah Abu Najm. Ibn al-Athir recorded that he died in 471/1078-1079 and that his body was buried in Tafunec. (Ibn al-Athir, n.d.-b: 10:108, 1987: 8:270) The reason why there are no records about the Jawanis in the period of Abu Najm is that Baghdad and its environments were calm compared to previous periods. During the period of Abul Fath, the Seljuks seized Baghdad, fought against Fatimids and Buwayhids, and also great events such as the Basasiri Revolt swept Baghdad. The Jawanis, who settled near Baghdad, were involved in these struggles, albeit unwillingly. In the period of Abu Najm, the Seljuks established dominance in and around Baghdad, the events took place far from Baghdad, and for this reason, the name of Abu Najm was mentioned less. 
After Togrul Bey passed away in 455, Alp Arslan ascended the throne. Alp Arslan sent a letter to the Abbasid caliph in 456 and asked him to have the khutbah read on his behalf. On April 28, 1064, a ceremony was organized by the caliph and it was decided that the khutbah be read in the name of Alp Arslan. The Abbasid judge sent a message to the emirs and requested that the khutbah be read in the name of Alp Arslan. Sibt Ibn al-Jawzi also mentions Ibn Varrām among the emirs who were sent news. Giving a khutbah is one of the symbols of the rulershi: According to the information given as Muslim b. Quraysh (Ukaylids), Dubays b. Mazyad (Mazyadids), Ibn Varrām and others, it is understood that the Jawanis were strong at that time. (Ibn al-Athir, n.d.-b: 10:47-48; Sibt Ibn al-Jawzi, 2013: 19:162)

The Jawanis also took part in the struggle between Alp Arslan and his uncle Qavurd. After Alp Arslan's died, Sultan Malikshah marched on Kirman against Qavurd Bey, who took action to become the ruler. Sultan Malikshah was victorious although the soldiers took Qavurd's side when they met near Hamadan. While the Sultan was attacking Qavurd's left flank, Sharafuddawlah Muslim b. Quraysh, Bahauddawlah Mansur b. Dubays b. Mazyad, and Kurds, including Arabs and Jawanis, attacked the right flank. Qavurd, who was captured after the war, was killed. Thus, the army of Malikshah, in which the Jawanis were also present, was victorious and Malikshah became the owner of the throne. While Ibn al-Athir accounts for the names of Ukaylids and Mazyadids, Sibt Ibn al-Jawzi mentions that Ibn Varrām had dinner with Malikshah during the war. The person whom Sibt named as Ibn Varrām is most likely Abu Najm. (Ibn al-Athir, n.d.-b: 10:82; Sibt Ibn al-Jawzi, 2013: 19:269) In 471, Sayfuddawlah Abu Najm Badran died and he was replaced by Abu Firas b. Varrām.

\section{Varrām b. Abu Firas (488-500)}

These two consecutive similar names may have been confused by historians. Perhaps, Abu Firas b. Varrām and Varrām b. Abu Firas are the same persons, but since the names are in that form in the records, we have to consider them as separate individuals. After this date, a close friendship emerged between the Jawanis and the Mazyadids. Bahauddawlah Abu Kamil Mansur b. Dubays b. Ali b. Mazyad al-Asadi, who was the ruler of Al-Hillah, al-Nil and other places around it, died in Rabee' al-awwal 479, that is, in June/July 1086. Sadaqah with Sayfuddawlah, with whom the Jawanis acted together, passed the throne instead of him. (Ibn al-Athir, n.d.-a: 10:137-138) It is understood that Sayfuddawlah Sadaqah took place with Barkyaruq in the Seljuk throne struggle between Tajuddawlah and Tutush b. Alp Arslan and Barkyaruq. Tutush appointed the Turkman emir Yusuf b. Abak as the Baghdad Shahnism 
(head of security). (488/1095) Abak, who wanted to plunder Baghdad, did not enter Baghdad and Sayfuddawlah Sadaqah, the Emir of Al-Hillah, marched on Abak. When Abak received the news that Tajuddawlah had died, he went to Aleppo. (Jawad, 1973: 19; Ibn al-Jawzi, 1992: 17:15; Ibn al-Athir, n.d.-a: 10:206) We learn from Ibn al-Jawzi that the Jawanis also took part in this expedition. When Abak learned that Sayfuddawlah Sadaqah had arrived and looted Tariqu Khorasan, Bajesra and its environs, the Abbasid vizier asked Varrām b. Abu Firas to prepare for war. Hajib cheated Varrām Ibn Abu Firas by conveying the opposite of what the vizier had said. However, at that time, when Tutush was defeated by Barkyaruq, the crisis was resolved. (Ibn al-Jawzi, 1992: 17:15) Other sources did not mention the Jawanis in this event which Ibn al-Jawzi briefly described and gave the name of Abu Firas. It is seen that Sayfuddawlah Sadaqah took part in many struggles during these dates. Al-Hillah, where the Jawanis were also inhabited, was the center of the emirate of Sayfuddawlah Sadaqah. In addition, it does not seem possible for the Jawanis not to be on the side of him since they are relatives. (Ibn al-Athir, n.d.-a: 10: 324) Sayfuddawlah Sadaqah went to Baghdad upon the caliph's request for help due to the unrest caused by Yinal, and played an active role in the conflict between Gumushtekin, Ilghazi and Sokman in the same year (Ibn al-Athir, n.d.-a: 10:289). -290), and invaded the city of Hit, which was in the hands of the Ukaylids. (Ibn alAthir, n.d.-a: 10:292) According to the agreement made between Sultan Barkyaruq and Mohammed in 497, the khutbah was to be read in the name of Sultan Mohammed on the territory of Sayfuddawlah Sadaqah. (Ibn al-Athir, n.d.-a: 301) In the same year, it is seen that Sayfuddawlah Sadaqah got stronger and invaded Wasit. (1104) The fact that the Jawanis were not mentioned as a party in these events that affected Baghdad and its surroundings does not mean that they were not involved in the events. During the time of Varrām b. Abu Firas, relations of alliance and friendship continued between the Jawanis and the Mazyadids.

It is understood that in 499 (January-February 1106), Sayfuddawlah Sadaqah dominated the localities up to Basra. Ismael b. Arslanjik ruled Basra and its environs. When Ismael fell out of Sadaqah and Sultan Mohammed's obedience, Sultan Mohammed ordered Sadaqah to take Basra from Ismael. We learn that there were Jawanis in the army prepared by Sadaqah because one of the Jawani leaders was murdered in the war. The reason for this is that it is rumored that Emir Abu Najm b. Abul-Qasim al-Varrāmi was killed in the clash between a Basraian tribe during the siege of the city by Sadaqah. Ibn al-Athir says that alVarrāmi is the son of Sayfuddawlah Sadaqah's uncle. Thanks to this information, we learn that the mother of Sayfuddawlah Sadaqah comes from the Jawanis. This shows the close kinships between the Jawanis and the Mazyadids. The alliances with Sayfuddawlah Sadaqah 
and the courage of Abu Najm were reflected in the poems written. (Ibn al-Athir, n.d.-a, p: 324-326, 1987: 8:520; Zarar Sadiq Tavfiq, n.d.: 64)

The Jawanis reaped the benefits of their kinship and alliance with the Mazyadids. Sayfuddawlah Sadaqah captured Tikrit in October 1106. Tikrit was under the control of Keyqubad b Hazaresb al-Daylami; and his people were treated very badly. The Seljuk Sultan Mohammed b. Malikshah sent Aksungur al-Porsuki to take Tikrit, and Kaykubad, who was in a difficult situation as a result, sent news to Sadaqah and handed over the city to him. When Keykubad died eight days later, Sadaqah appointed Varrām b. Abu Firas b. Varrām as regent to Tikrit. (Jawad, 1973: 21; Ibn Khaldun, 2000a: 4: 365; Ibn al-Athir, n.d.-a: 10: 337-338)

While talking about the death of Sadaqah b. Mazyad, Ibn al-Athir says that he was the founder of the Al-Hillah al-Sayfiyyah (حلة السيفية) in Iraq. ${ }^{6}$ The strengthening of the Jawanis with the Mazyadids continued until Rajab 501 (March 1107). This rise stopped with the murder of Sadaqah. Sadaqah did not leave Sultan Mohammed b. Malikshah alone in any war and increased his iqta. Amid Abu Jafar Mohammed b. Husayin al-Balhi broke up the relationship between the Sultan and Sadaqah. He said that Sadaqah became very powerful, that he protected those who fled from the sultan, and interfered in state affairs and became a Batinî. This instigation brought Sayfuddawlah Sadaqah and Sultan Mohammed face to face. For a long time, the problem was tried to be solved with the intervention of the caliph, but it did not yield any results. Sayfuddawlah Sadaqah was killed in the war after 21 years of being an emir, and after his death, the reign of the Mazyadids was shaken. His son, Dubays, who was captured, and released after he swore that he would not commit mischief. (Ibn al-Athir, n.d.-a, p: 359-360) With the defeat in this war, Mazyadids lost their gains that they had achieved for years. Difficult times began for both Mazayids and their allies, the Jawanis, and the information from the sources about Varrām b. Abu Firas was cut off.

\section{Emir Abu Shuja Asim b. Abu Najm b. Varrām al-Kurdi}

In the year 501, in the war between Sultan Mohammed b. Malikshah and Sayfuddawlah Sadaqah, the Jawanis Kurds sided with Sayfuddawlah Sadaqah and were defeated together with him. After this date, Sultan Mohammed tried to bring the Kurds to heel with the Kurds through political means. He gave the lands of the Mazyadids and Jawanis to a Kurd called Sayakil. This situation has been the subject of some poems, especially Abu

\footnotetext{
${ }^{6}$ It was named as al-Hillah al-Sayfiyyah due to his name, Sayfuddawlah.
} 
Shuja Asim b. Abu Najm al-Jawani. (Jawad, 1973, p: 22-23; Al-Isfahani, 1973a, p: 4/2:421424; Al-Safedi, 2000: 10:60; Al-Dahabi , 2003: 11:499)

Al-Isfahani says that Emir Abu Shuja Asım b. Abu Najm al-Kurdi was one of the prominent personalities of the Jawanis Kurds and that the Jawanis were residing at the bottom of Wasit, on the bank of the Tigris River. According to him, Asim invaded the places from the Berhada River (برحدا) to Siniye, (الصينية) and Qaryetu Abu Najm, which was next to Farus, the name of which was attributed to his father. It is attributed to Asimiyyah, that is, Barhada, which is one of the important cities. This place should be the real homeland of the Jawanis. Later, they will be famous for al-Hillah and known for this place. Al-Isfahani wrote praising sentences about Asim b. Abu Najm. He says that he is a valuable person, a heroic warrior, as brave and powerful as a lion, and a great person. He states that he alone hunted fifty lions in his life and that he was mentioned a lot due to his courage and literary aspect, and that he had beautiful poems. (Jawad, 1973: 22-23; Al-Isfahani, 1973a: 4/2: 421-424) There is no information about when this Kurdish emir died.

It is reported that in 502/1108-1109, Mansur b. Sadaqah b. Mazyad appeared before the Sultan and their relations got better. His brother Badran b. Sadaqah also became friends with the sultan's governor of Mosul (Ibn al-Athir, n.d.-b: 10:376). From this date until 512, he stayed with the sultan, the sultan treated him very well and gave him many places as iqta. When Sultan Mohammed died and was succeeded by Mahmud, Dubays took permission from Sultan and returned to Al-Hillah, where he gathered many people from Arab, Kurdish and other tribes around him (Jawad, 1973: 27; Ibn al-Athir, n.d.-b:10:424).

\section{Muhalhil and Anter b. Abul Asker Brothers}

Mazyadi leader Dubays b. Sadaqah went to his lands in 516/1122-1123 and continued his power with the Jawanis. That year, the enmity between the Abbasid caliph al-Mustarshid and Dubays b. Sadaqah increased. It was so much that the caliph wanted Dubays to be taken out of Iraq. The caliph, who wanted to get rid of Dubays, asked the Seljuk sultan to send Aksungur al-Porsuki from Mosul. He wanted al-Porsuki, who would protect him against Dubays, to be appointed as the Baghdad security head, and this offer was accepted by the sultan. When Dubays put the caliph al-Mustarshid in a difficult situation, al-Porsuki marched on Al-Hillah by the order of the caliph, but al-Porsuki was defeated in the war that took place

\footnotetext{
${ }^{7}$ Berhada River: the correct spelling is Barjada.
} 
between them. Afterwards, Dubays and the Turks came face to face. When the Turks did not let their men to go to Wasit to act on the order of Dubays, Dubays sent an army against the Turks under the command of Ziyauddin Muhalhil b. Abul Askar al-Kurdi al-Jawani. ${ }^{8}$ Muzaffer b. Abul Jabr from Batiha was also sent to Muhalhil's aid. Meanwhile, al-Porsuki reinforced his men in Wasit. When Muhalhil attacked here without waiting for Muzaffar, Muhalhil's army was defeated on 9 Rajab (13 September 1122). While Wasitians had very few casualties, Muhalhil's army both lost a lot of soldiers and important people were captured. (Jawad, 1973: 27; Ibn Khaldun, 2000b: 4:686-687; Ibn al-Athir, n.d.-a: 10:473474)

As it can be understood from the expression and names mentioned by Ibn al-Athir, Muhelhil b. Abul Asker and Anter b. Abul Asker are brothers. (Ibn al-Athir, n.d.-a: 11:6263) The alliances of Dubays b. Sadaqah and Anter b. Abul Asker were reflected in the poems of the poet Hays Bays. (Hays Bays, 1974: 320)

In 517, the Jawanis under the command of Dubays b. Mazyad fought against Aksungur al-Porsuki, the commander of the Caliph Mustarshid. Al-Mustarshid had sent alPorsuki to war with Dubays, and the Seljuk sultan had put a hot iron in the eye of Dubays' brother. Dubays sent a threatening letter to al-Mustarshid and wore mourning clothes. While Dubays set out on an expedition in Ramadan 516 by targeting Baghdad, al-Mustarshid brought Karvash b. Muslim and some of his emirs with him. In Muharram 517 (March 1123), the caliph and al-Porsuki came face to face with Dubays in the village of al-Mubaraka in the east of the Middle Euphrates. Emir Fahruddin Abu Mohammed Anter b. Abul Asker al-Kurdi attacked Porsuki's right flank with some of the soldiers of Dubays, but they failed and returned. Anter's second attack also failed. Soldiers from Wasit attacked the soldiers of Imamuddin Zengi b. Aksungur and Anter and captured Anter and Barik b. Zaida. Al-Porsuki and the caliph's soldiers dispersed Dubays' army. While Dubays' women and concubines were taken captive, he himself escaped. Dubays sought refuge first with the crusaders and then with Malik Togrul b. Sultan Mohammed and tried to make them attack Iraq (Jawad, 1973: 27-28; Al-Dahabi , 1993: 35:297; Ibn Haldun, 2000b: 3:621; Ibn Kathir, 1987: 16:257; Ibn al-Jawzi , 1992: 17:217; Ibn al-Athir, n.d.-a: 10:481-483, 1987: 8:684). After this defeat,

\footnotetext{
${ }^{8}$ Ibn al-Adim says that the poet Emir Shihabuddin al-Hays Bays was with Emir Muhalhil al-Jawani in the alHillah of Mazyadids (Ibn al-Adim, n.d., : 9: 4265). Talking about the poet Hays Bays, Ibn Hallikan mentions an incident he had with Ziyauddin Muhalhil b. Abul Asker al-Jawani. It is seen that the poet and Ziyauddin Muhalhil have old friendships and are referred to as the governor of Ziyauddin Hillah. (Ibn Hallikan, 1977: $2: 363$ ) The same story was narrated by al-Safadi, too. See (As-Safadi, 2000, : 15:103)
} 
it is seen that Dubays could not take shelter in Al-Hillah. The Mazyadi leader, who was the relatives and allies of the Jawanis, was in a difficult situation due to his enmity with the Abbasid caliph and the defeat they had. The fact that al-Hillah and Wasit are in the hands of their enemies and that they are ruled by them indicates this. (Ibn al-Athir, n.d.-a: 10: 495, $516,517,528,433,535)$

On 4 Muharram 521 (January 20, 1127), a group of soldiers of Sultan Mahmud entered Dar al-Khalifah and began to loot the surroundings. There were clashes between the Sultan's soldiers and the caliph's men. Abul Fath b. Varrām's name is also mentioned in this incident in which Dar al-Khalifah was also plundered. It is said that Abul Fath only betrayed the men with him and went to the side of the sultan. (Ibn al-Jawzi, 1992: 17:241-242)

In 530, a war broke out between the caliph al-Rashid Billah and the soldiers of Sultan Mahmud due to the refusing the payment of the money demanded from the caliph. There were clashes in Baghdad between the Seljuk soldiers and the army of the caliph. Meanwhile, when Malik Davud b. Sultan Masud went to Baghdad in 4 Safar (13 November 1133), many emirs and judges gathered to rebel against Sultan Masud. Anter b. Abul Asker, one of the Jawanis leaders who carried out their affairs, was with Sadaqah, who was with Malik Davud against Sultan Masud. When the caliph started to deliver the khutbah on behalf of Malik Davud (Ibn al-Athir, n.d.-b: 11:41-43, 1987: 9:72-73), Sultan Masud, hearing this, came to Baghdad with his soldiers and besieged the city. Emirs with Malik Davud and al-Rashid Billah were dispersed and al-Rashid Billah was dismissed. (Ibn al-Athir, n.d.-a: 11:45-46) Sultan Masud settled the affairs in Baghdad. The caliph married the sister of Sultan Masud and also Sultan Masud tried to establish strong ties with, Sadaqah b. Dubays b. Sadaqah, by establishing kinship with him. (Ibn al-Athir, n.d.-b: 11:52)

In 532/1137-1138, the fight for the throne between Sultan Masud and Malik Davud triggered the events leading to the death of Anter b. Abul Asker and Sadaqah b. Dubays. Persian ruler Mangupars, regent of Khuzestan Emir Bozaba, Emir of Halhal Abdurrahman Togayurak and Malik Davud b. Sultan Mahmud united and formed an alliance with al-Rashid Billah, who came to Maraga and opposed to Sultan Masud. When Sultan Masud heard this, he took action in Sha'baan (April-May 1138) and defeated Mangupars and captured him. When Sultan Masud was alone for a while, he was attacked and defeated. Many emirs, including the rulers of Al-Hillah, Sadaqah b Dubays and Anter b. Abul Asker, were captured and killed. After Sadaqah b. Dubays was killed, Sultan Masud sent his brother Mohammed b. Dubays to Al-Hillah and Muhalhil b. Abul Asker, brother of Anter b. Abul Asker, as administrators to the city. (Jawad, 1973: 29; Ibn Khaldun, 2000a: 3:634; Ibn al-Athir, n.d.-b: 
11:62-63, 1987: 9:94) Muhalhil, who would now serve as the assistant of the Mazyadi leader, Mohammed b. Dubays, also entered the service of the Seljuks.

Ibn al-Fuwati opened a topic about Anter b. Abul Asker, who was killed in this war. He recorded his name as Emir Fahruddin Abu Mohammed Anter b. Abul Asker al-Jawani. He says that Anter was a generous and courageous emir, and that he was praised. Ibn alFuwati saw and transferred the poem written by Anter. (Ibn al-Fuwati, 1416: 3:99-100)

In 540/1146, we come across some records about the Jawani Emir Muhalhil. The Persian and Khuzestan ruler Bozaba together with Sultan Mahmud's sons Malik Mohammed, his son Malik Suleymanshah and Rey governor Abbas rebelled against Sultan Masud. Emir Abdurrahman Togayurak, who was on the side of Sultan Masud and ruled the state, was also on their side. Sultan Masud left Baghdad in Ramadan (February-March 1146), and then Emir Muhalhil went to Baghdad. This means that Emir Muhalhil is a party to the event, but it is not clear who is on his side. When the parties approached each other, they did not fight and agreed in terms among themselves. In the same year, it is seen that Muhalhil contradicted the Mazyadids. It seems that their long-lasting alliance broke down despite their kinshi: When Sultan Masud decided to leave Baghdad, Muhalhil asked him to imprison Ali b. Dubays in Tikrit. When Ali understood this, he gathered people from Banu Asad and other tribes and attacked al-Hillah, which was in the hands of Mohammed b. Dubays, defeated him and took al-Hillah. Sultan Masud, who was indifferent to this at first, saw that Ali was getting stronger; therefore, sent Muhalhil with soldiers, but Muhalhil lost the war and returned to Baghdad. The people of al-Hillah were so attached to Ali b. Dubays that when Muhalhil went out, they cursed him. For that reason, Muhalhil did not want to go out. After a while, Ali b. Dubays and the caliph made an agreement with the sultan. (Ibn al-Athir, n.d.-b: 11:99-100, 1987: 9:137-138; Sibt Ibn al-Jawzi, 2013: 20:354) In this century, rivalry arose between the Mazyadids and the Jawanis because the Jawanis experienced that their affairs would improve by subjecting them to the Baghdad Abbasid caliph. Banu Assad's alliance with the Seljuks and his opposition to the Abbasids were making his dreams of returning to Al-Hillah to be in vain. (Jawad, 1973: 30)

The names of the Jawanis and their leader Muhalhil are also mentioned in the incident that Ibn al-Athir said took place in 549 and al-Husayni in 550. This record, in which Muhalhil is commemorated, is related to the siege of Tikrit and the Battle of Bikamza (Bicamza) in 549, in which the Jawanis sided with the Abbasids. The caliph wanted the prisoners in Tikrit to be released, but when his ambassador was arrested, he went on a campaign in person at the beginning of Safar, besieged the city (1154) but could not take it. Then the vizier Avnuddin 
b. al-Hubayrah besieged the city, but when he heard that Masud al-Bilali was marching on them with Alpkush, Gunhar and Turshek, he returned to Baghdad. Masud al-Bilali prepared for war against the Abbasid caliph by sending news to Tikrit and releasing Malik Arslan $b$. Sultan Togrul b. Mohammed from prison. In the war between the Abbasid army and Masud al-Bilali, who faced each other in Bikamza, the caliph overrode his opponents and won a lot of booty. In this war, in the army of the caliph al-Muktafi Liamrillah, there were the Emir of Al-Hillah Muhalhil and the Jawanis Kurds. Al-Husayni mentions that Muhalhil was against the caliph and was defeated in the battle. Ibn al-Athir also says that Hindi al-Kurdi (alJawani) betrayed the caliph and crossed over to the other side together with the sons of Avf. Muhalhil took the side of Masud al-Bilali in this war and lost his gains. (Jawad, 1973, p: 3132; al-Husayni, 1933, p: 131-132; Ibn al-Athir, n.d.-b, p: 11:167-169) ${ }^{9}$

In the year that Ibn al-Athir recorded as 551 and other historians as 552, the Seljuk Sultan Mohammed b. Mahmud went against the Caliph, al-Muktafi, in 1157 and besieged Baghdad because he did not give a khutbah on his behalf. The caliph sent news and asked for help, upon this, Hatalpars set off from Wasit, and Erkush, the ruler of Basra, rebelled and captured Wasit. Muhalhil, who took advantage of this turmoil, took the city of al-Hillah. During the long siege of Baghdad, many people were killed, but the city did not surrender, although the people suffered greatly. When Sultan Mohammed's brother Malikshah and Ildeniz invaded Hamadan, the siege was lifted and Sultan Mohammed had to return. (alHusayni, 1933, p: 136-137; Ibn al-Athir, n.d.-b: 11:183; Sibt Ibn al-Jawzi, 2013: 20:468) In this siege, Banu Asad, in other word, the Mazyadids, took their place beside the Sultan and showed themselves. Ali b. Dubays and his uncle's son Hasan al-Matrab ruled the Mayzadids. Hasan was taken prisoner in the war and many of the people of al-Hillah were killed. Ibn alJawzi says that Muhalhil went to al-Hillah and that the sons of Avf captured al-Hillah. (Jawad, 1973: 33-34; Ibn al-Jawzi, 1992: 18:111) As it is understood, Muhalhil acted against the Sons of Avf and Seljuks in the ranks of the caliph. The Sons of Avf, who marched to alHillah, captured it. (Zarar Sadiq Tavfiq, n.d.: 67)

After this incident, there is no record of Muhalhil. He probably died after this date or was not included in the records because he did not take part in an important event or was not mentioned any more. However, the names of some of his sons are encountered. Abul-Fawaris Husamuddin Badr b. Muhalhil b. Abul Asker and Emir Nusretuddin Ismael b. Anter b. Abul

\footnotetext{
${ }^{9}$ For the poem written by Heresi about Muhalhil, see Jawad, 1973: 32.
} 
Asker, whom the poet Hays Beys praised in his divan, are the sons of Muhalhil and Anter. (Hays Beys, 1974: 1: 297; 2: 22, 24, 295; 3: 38, 346)

In the year 557/1161-1162, an event occurred that shook the power of the Jawanis. Abbasid caliph al-Mustenjid Billah wanted to put an end to the instignation and mischief of the Mazyadids. Because the Mazyadids supported Sultan Mohammed during the siege of Baghdad. Yazden b. Kamaj was appointed to expel them from their homeland. Ibn Kamaj, with the support of al-Muntafik, the Emir of Basra, marched on the Mazyadids and besieged them. At the end of the war, in which four thousand people died, the Assadis had to surrender. In Al-Hillah, the callers called out, "The blood of those who stay in al-Hillah is halal (permitted to be shed)." After they called out, the Asadids completely left Iraq. There is no record that the Jawanis were also exiled. But Zarar Sadiq, based on the record of Hamdullah Mustawfî, says that some of the Jawanis may have gone to Luristan. After this exile, very little information was conveyed from both the Asadids and the Jawanis. The Jawanis could no longer be in power or power partners as before, but were referred to with more secondary duties. For this reason, it is possible to say that the expulsion of the Mayzadis from Iraq caused the weakening of the Jawanis. The expulsion of Mayzadis and Jawanis from Al-Hillah and Bataih was considered as the end of the Jawani Emirate. (Ibn al-Athir, n.d.-b: 11:242; Zarar Sadiq Tavfiq, n.d.: 68) Based on the following records, we believe that this supposition is correct.

\section{Some Jawani Emirs after Losing their Domination}

After the weakening of Jawani dominance with the exile of the Mazyadids in 557, it is seen that there were some Jawani leaders who appeared in the sources on various occasions. After this date, we see that the Jawanis leaders, who are mentioned, came to the fore with various secondary duties such as scholars, security officers and pilgrimage emirs, and that the Jawanis became Shiite. The names of some Jawanis leaders and scholars that we were able to be identified in the sources are as follows:

\section{Abul Qasim Al-Muzaffer b. Tahir b. Mohammed al-Jawani}

We can find brief information about Abul-Qasim from the records of al-Farisi. It is understood that he is a descendant of one of the Jawani emirs. The reason for his reflection in the sources is that he is a virtuous scholar, takes lessons and owns works. We only know that he had lessons from Abu Zakariyya Yahya b. Abdurrahman b. Mohammed al-Kirmani. Since 
al-Farisi died in 529/1134-1135, Abul-Qasim probably lived close to his time. (Al-Farisi, 1989: 9, 451)

\section{Sharafuddawlah Mohammed b. Varrām}

It is known that Sharafuddawlah Mohammed b. Varrām, brother of Saifuddawlah Abu Najm Badr b. Varrām al-Kurdi (d. 472/479), built a Shāfi '̄̄ madrasa for in Wasit. Teaching Shäfi ' $\overline{1}$ fiqh here shows that the Jawanis, who later became Shiites, were Shāfi' $\overline{1}$ at that time. Tajuddin al-Subki says that Abu Ali al-Hasan b. Ahmed b. Abdullah al-Wasiti gave lectures in Madrasah of Ibn Varrām in Wasit in 576/1180-1181. In the Wasit History of Eslam b. Sahl al-Razzaz, it is recorded that this year is 573. (Bahshal al-Wasiti, 1406: 1:264; Jawad, 1973: 22-23; al-Subki, 1413: 7:60; Zarar Sadiq Tavfiq, n.d.: 55)

\section{Emir Abul-Hayj Abdullah b. Haris b. Varrām}

Jamaluddevle Sharaf al-Kitab Mohammed Ibn Jayya from Hilla as-Saifiyyah wrote a long poem praising Emir Abul-Hayj b. Varrām al-Kurdi. The fact that Ibn Jayya, one of the noble poets of the Arabs, introduced him as an emir and praised him means that he was an important person. (Jawad, 1973: 35; Al-Isfahani, 1973b: 195, 197-202)

\section{Emir Qasimuddawlah Taglib al-Jawani}

Ibn al-Fuwati says that he saw in the work of Vizier Muayyuddin Abu Talib Mohammed b. al-Kumi that Ibn Usama al-Alawi studied in the madrasa of Emir Qasimuddawlah Taglib al-Jawani. (Ibn al-Fuwati, 1416: 3:348-349) We do not know the date of birth and death of Qasimuddawlah, only it is mentioned in the sources that Usama was born in 559/1163-1164. Based on this information, it is understood that he lived in the last quarter of the VI century. (Jawad, 1973: 37; al-Safadi, 2000: 3:182)

\section{Abu Said Mohammed b. Ali b. Abdullah b. Ahmad Hamdan al-Jawani al-Hilli al-Shāfi î̃}

Due to being a Shāfi ' $\overline{1}$ scholar, he is one of the Jawanis figures who find the largest place in Islamic history sources. Since his name was mentioned together with his ancestors, historians could not write and list them in the same way. It is possible to accept its most general form as Abu Said Mohammed b. Ali b. Abdullah b. Ahmad Hamdan al-Jawani alHilli al-Shāfi $\overline{1}$. His date of birth is given as 470/1077-1078. (al-Subki, 1413: 6:152; Ibn alMustawfi, 1980: 1: 497; 2: 94-95). Ez-Zirikli and Katip Chelebi (Çelebi) claim that he was born in 468/1075 (Ez-Zirikli, 1085: 2:270; Katip Chelebi, 1941: 2:1255-1256) Some of the 
historians also emphasized that he was from the Jawani Kurdish tribe. (Jawad, 1973: 45; alAsnevi, 1987: 1:179; Al-Subki, 1413: 6:152; al-Dahabi , 2003: 12203; Ez-Zirikli, 1085: 2:275; Ibn Kathir, 2004: 607; al-Firuzabadi, 2005: 1:1188; Ez-Zabidi, 2001: 34:387)

It is al-Dahabi who wrote his scientific story in the best way. Mohammed, who came to Baghdad as a child, took fiqh lessons from al-Ghazali and al-Herrasi, who were the professors of the Baghdad Nizamiye Madrasah, and hadith lessons from al-Ghazali's al-Cami all-Awwam. While he was educated by Hariri, he read al-Maqamat, which is his work. Abu Bakr Mohammed b. Ahmad al-Shashi, Humaydi, Abu Abdullah Mohammed b. Ali al-Iraqi, Abul-Fawaris al-Hasan b. Abdullah b. Shāfi '̄i ed-Dimeshki, Abu Sad Abdulvahid b. Kushayri and Kadi Abu Bekir Mohammed b. Muzaffer al-Shami are the names mentioned that he had lessons from. Kadi Usyut Abul Barakat Mohammed b. Ali al-Ansari took hadith lessons from him. Kadi Usyut wrote that Radiyuddin al-Jawani, who was his sheikh and imam, took lessons from him in Mosul in the year of Rajab 559/1163-1164. Among the places where he lived and studied, the names of the cities of Baghdad, Mosul, Arbil and Bavazij are mentioned. (al-Babbani, n.d.: 4:134; al-Asnevi, 1987: 1:179; al-Safadi, 2000: 4:112-113; 11:32; 24:99; al-Dahabi , 2003: 12: 203; Ibn Kathir, 2004: 1:649; Ibn al-Mustawfi, 1980: 1: 497; 2: 94-95)

Mohammed, who was a poet, was a gifted scholar in debate. He compiled the book named Al-Maqamat al-Hariri and wrote the books called Kitab fi Tavhid, Uyun as-Shiir, ${ }^{10}$ alFark Bayn ar-Ra and Gayn (al-Safadi, 2000: 4:112-113; al-Dahabi, 1993: 38:361-363; Katip Chelebi, 1941: 2:1255-1256; Zarar Sadiq Tavfiq, n.d.: 55). Ibn al-Mustawfi states that Mohammed, whom he describes as a literary scholar, wrote many works, and that he was a scholar of grammar and lexicon, and that he also wrote the work al-Zahirah: Li Ahl alBasirah. (Ez-Zirikli, 1085: 2:270; Ibn al-Mustawfi, 1980: 1: 497; 2: 94-95)

There are different narrations about the date of death of Abu Said Mohammed (Ibn alAdim 550, Dahabî 560, Ibn al-Kathir 560, Katip Çelebi 561, al-Safadi 561). Ibn al-Mustawfi said that he died in Haftiyan in 561. (Ibn al-Mustawfi, 1980: 1: 497; 2: 94-95; Ibn al-Adim, n.d.: 1:26; Al-Dahabi, 2003: 12:203; al-Safadi , 2000: 4:112-113; Katip Çelebi, 1941: 2:1255-1256; Ibn Kathir, 2004: 1:649)

\footnotetext{
${ }^{10}$ According to Ibn Kathir, it is Garib al-Shiir. See (Ibn Kathir, 2004: 1:649).
} 


\section{Abul Hasan Varrām b. Abu Firas Isa b. Abu Najm}

In his work called Tanbih al-Hawatir ve Nuzhat an-Nawazir (Varrām b. Abu Firas, 2013: 14), ${ }^{11}$ it is said that his name is Abul Husayin Varrām b. Abu Firas Varrām b. Hamdan b. Abu Najm b. Varrām b. Hamdan b. Hulan b. Ibrahim b. Malik b. Haris al-Ashter en-Nahi al-Ashteri al-Hilli. Ibn al-Athir reports that he was an ascetic. Al-Zirikli wrote that he was first-of-all a soldier that he wore military clothes and put on a sword, and used to leave them to pray. He was mentioned among the people of Al-Hillah who were mentioned with virtue. (al-Zirikli, 1085: 8:113; Ibn al-Athir, 1987: 10:271) Mustafa Jawad says that they left the tribal affiliation (nisbah) of al-Kurdi and compared themselves to Ibrahim b. Malik al-Ashter and that this was because they were Shiites. Just as some Kurds identify themselves with Uthman b. Affan, Khalid b. Walid and Banu Abbas, they also associated themselves with famous Arabs. (Jawad, 1973: 37-39)

It is understood from both historical records and the works he wrote that Abul Hasan Varrām, who is said to have miracles, was a scholar (al-Dahabi, 1993: 42:493; Ibn Hajar elAskalani, 2002: 8:375) and afterwards, it is seen that there are quotations from his books from himself. (al-Khorasani, 1390: 2:170,182; 4:320,337: 5:153,155,331; 6:21,160; $7: 158,161,231,253)$ When the caliph went to al-Hillah, he bestowed on him, but he did not accept it. (Sibt Ibn al-Jawzi, 2013: 22:168) Abul Hasan Varrām, who is said to have lived in Al-Hillah, died there in 2 Muharram 605 (July 17, 1208) and was moved to Kufa and buried in the Martyrdom of Hazrat Ali. He made such a choice because he was a Shiite. (al-Babani, n.d.: 2:479; 3:324; Ibn al-Athir, 1987: 10:271; Ibn al-Sai, 1934: 9:271; Sibt Ibn al-Jawzi, 2013: 22:168) Some have said that he died in 650, but this is highly unlikely. (al-Zirikli, 1085: 8:113; Ibn Hajar al-Asqalani, 2002: 8:375) It is certain that Abul Hasan Varrām, who was both an emir and a scholar, had an impact on the spread of Shi'ism among the Jawani Kurds.

\section{Husamuddin Abu Firas al-Hilli al-Kurdi al-Varrām}

Dahabi recorded his name as Mohammed b. Abu Jafar or as Ibn Jafar b. Yahya b. Mohammed b. Abu Firas al-Emir Husamuddin Abu Firas al-Hilli. Ibn al-Athir introduced him as Husamuddin Abu Firas al-Hilli al-Kurdi al-Verrami in one place and as Abu Firas b.

\footnotetext{
${ }^{11}$ Also, he has a work called Masala fi al-Muvasiah ve al-Mudayikah. See Varrām b. Abu Firas, 2013: 35.
} 
Jafar b. Firas al-Hilli in another place. Ibn al-Fuwati gave his name as Husamuddin Ali alHaj. (al-Dahabi, 1993: 47:96; Ibn al-Athir, 1987: 10:285, 406; Ibn al-Fuwati, 2003: 31)

Husamuddin, who was said to be a very brave man, was respected in Baghdad. He assumed the regency of Wasit, and when he fell out with the Vizier Muayyiduddin al-Qumi, he went to Damascus and then to Egypt and took refuge in Malik Kamil and he was respected. When the vizier was dismissed, he returned and his rank and fief were restored to him. A golden sword, horse, drums, flags and soldiers were given to him, and Dakuka, or Tavuk, with its current name, was given to him as a tax farm. (Persian: $i q t \bar{a}^{`}$ ) (al-Dahabi, 1993: 47:96; Ibn al-Fuwati, 2003: 52, 2003: 52)

The reason why he is included in so many records is that he was the pilgrimage emir of the Abbasids and relatively due to the events that took place during the pilgrimage. It is seen that he served as a pilgrimage emir many times. Sibt Ibn al-Jawzi says that in 607 and 608, Abu Firas was with Mohammed b. Yaqut during the pilgrimage and helped him in religious matters. Abu Firas guided Mohammed, who was a child, in the events in which the pilgrims were killed and plundered in Mecca. (al-Dahabi, 1993: 43:35; Sibt Ibn al-Jawzi, 2013: 22: 173,192) After this date, it is seen that Abu Firas was appointed as the pilgrim emir. Historians say that in the first period, he fulfilled his duty of pilgrimage emirate in 609 , $610,611,612,613$. Sibt says that during the pilgrimage made in 618, Abu Firas brought a letter to Abu Nasr that the administration of Mecca and Medina was covenant. It is also known that he undertook the pilgrimage in 614, 620, 621, 622 and 623. (Jawad, 1973, p: 4142; al-Dahabi, 1993: 47:96; Ibn Taghribardi, 1935: 6:206, 208, 211; Ibn al-Athir, 1987: 10: 285; Ibn al-Fuwati, 2003: 52; Sibt Ibn al-Jawzi, 2013: 22:186,192, 195, 200, 207, 219, 259, $263,271,274)$

In 622/1225-1226, he quit his duty of the Emir of Hajj and went to Egypt. The fact that the Abbasid caliph did not support him was effective in his going to Egypt and taking refuge with the Ayyubids. While most of his companions perished on the way, he managed to get there safely. Husamuddin, who was given the task of command by Malik Adil, returned only after Vizier Muayyiduddin al-Qumi was arrested in 629/1231-1232. He wrote to the caliphate council and asked for permission to return, and when he returned, he was reinstated. (Jawad, 1973, p: 42-43; Ibn al-Athir, 1987: 10:406; Ibn al-Fuwati, 2003: 52)

It is seen that Husamuddin's father was also an important person. According to Ibn alFuwati, his father, Mujiruddin Jafar b. Abu Firas al-Hilli, returned to Baghdad from Egypt with Husamuddin in 628. When he arrived, he received the consent of Caliph al-Mustansir 
Billah. He served as Basra and Wasit Shahnekiyye (military governor). While his son was the pilgrimage emir, he went on a pilgrimage with him and was buried in the Martyrdom of Hazrat Ali after he died. (Ibn al-Fuwati, 2003: 31) Ibn al-Athir says that the uncle of Husamuddin Abu Firas al-Hilli al-Kurdi, Emir of Hajj in Iraq, was Ibn Abu Sheikh Varrām. (Ibn al-Athir, 1987: 10:406)

Ibn al-Fuwati says that Kayran al-Zahiri was dismissed from the special pilgrimage emirate in 632/1234-1235 and Emir Husamuddin Abu Firas b. Jafar b. Abu Firas was brought in his place. Ibn al-Fuwati says that Husamuddin served as the pilgrimage emirate in 632, 633, 634, after 634, the pilgrimage expeditions were interrupted and in 638, Husamuddin Abu Firas b. Jafar b. Abu Firas was dismissed from the pilgrimage emirate. (Ibn al-Fuwati, 2003: 82, 83)

\section{Imaduddin Abul Muzaffer Mohammed}

Ibn al-Fuwati recorded his name as Emir Imaduddin Abul Muzaffer Mohammed b. Abu Firas Husamuddin al-Haris b. Jafar b. Abu Firas al-Nahi al-Hilli. He described his family as a family of emirs and governors. He transferred a narration from Tajuddin Ibn Sai as follows: "In Rabi-ul-Awwal 635/1237-1238, he was chosen as the security head of alHillah. Afterwards, he was dismissed from his position in 643 due to his actions and Qutbuddin Sanjar al-Bakaki took his place. After a while, he was appointed to the head of the security of Kufa, replacing Emir Akkoush al-Shami. He was also dismissed from this post due to financial issues and neglect of business. He was killed in the battle between Hulagu and the Abbasids in 656/1258." (Jawad, 1973: 43; Ibn al-Fuwati, 1963: 4/2: 813)

\section{Mohammed b. Shube b. Juwan al-Jawani}

Al-Semani did not mention about the affiliation of Jawani in his work. Yet, he opened a title with the name "al-Juwani." He gave the name of Halef b. Hasan b. Jawan al-Wasiti alJawani, who is known with this affiliation. What makes this information important for the Jawanis is that Wasit passes among the places where the Jawanis lived. In addition, Semani also mentions Mohammed b. Shube b. Juwan al-Juwani, whom he says is from Baghdad. (alSamani, 1988: 2:106) 


\section{Husayin b. Abu Tahir Ahmad b. Mohammed b. Husayin al-Jawani}

Apart from this, the name of Husayin b. Abu Tahir Ahmed b. Mohammed b. Husayin al-Jawani, one of the Seljuk Shiite muhaddis who lived during the Seljuk period and about whom we have little information, is known. (Zarar Sadiq Tavfiq, n.d.: 56)

\section{Conclusion}

The similarity of the words Jaban and Jawan gives the impression that they are related. As a result of the researches in the sources, no information could be found that the Jawanis were descendants of Jaban al-Kurdi. Since the word coded as Jawan in Arabic is not in Kurdish, it is believed that it is Gavan, meaning cattle herder.

The earliest recorded document about the Jawani Tribe is in the work of Masudi, who died in 956. The fact that they existed as a tribe at this date shows that their roots go back much further. The emergence of the Jawanis as a political power coincides with the year 1002 CE. After this year, we can say that the Jawanis existed as an emirate. Because they are among the few important emirs whose names are mentioned in the events that took place in and around Baghdad. Despite the superficial information presented about them, there are some indications that convince us that they are an emirate. The fact that they took part in the most important events with their military forces, and that their leaders were referred to as emirs, and that they delivered khutbah and that they were given a robe of honour and conquered land indicate this.

The Jawanis sometimes joined the alliances established against the Abbasid and Buwayhid governments, the greatest powers of the Islamic world, and sometimes took their side. Likewise, they sometimes allied with the emirates in the region and sometimes fought with them. The Jawanis, who were a party to the internal conflicts of the Seljuks, Buwayhids, Annazids and Mazyadids, fought against the Kurds, Arabs and Turks, although they were Kurds. From the Seljuks' establishment to their enterance in Baghdad (1040-1055), it was one of the emirates that resisted them the most, but after the balances changed, they also changed their stance.

The Jawanis consolidated their alliance with the Mazyadids through marriage. Thanks to this alliance, it can be said that the Mazyadids have reached a more powerful position. The fact that they founded the city of al-Hillah together in this period and that they were associated with the same city creates the impression that they are united as well as have relations of kinship, alliance and friendshi: During the siege of Baghdad by the Seljuks in 
552/1157, the support of the Mazyadids pushed the Abbasids to get rid of the Mazyadids. After the year 557/1161-1162, when the Mazyadids were driven out of Iraq from al-Hillah, the signs that the Jawani emirate continued seem to have disappeared. It is observed that the Jawani emirs, who seem to have lost their power, took on secondary duties such as pilgrimage emirs and security head after this date, and showed themselves as scholars who compiled various works.

We understand that the Jawanis were first Shāfi '⿳亠丷冖 ; Shāfi '`̃ Fiqh was taught at Ibn Varrām's madrasa, as mentioned in the sources. Towards the end of the fifth century, the Janwanis gradually became Shiite. Some of the Jawani Shiite emirs wrote books on their own beliefs and their books were accepted. With the influence of Shiism, it is seen that the Jawani emirs in the last period were associated with Malik al-Ashtar. Although Jawanis were mentioned in the sources until the eighteenth century, it is understood that they lost their Kurdish identity and became Arab due to their belief in Shiisim. Except for the name of the neighborhood called "Mahalla al-Akrad" today, no trace of the Jawaniyya can be found in alHillah.

\section{References}

Abud, A. F. (2010). Madinat Hillah Minzo Tasisiha Hatta Nihayat al-Karn al Tasi Aşara alMiladi. Camiat Babil. http://art.uobabylon.edu.iq/lecture.aspx?fid= $8 \&$ lcid=885 75 .

Al-Asnevi, A. (1987). Tabakat al-Shafiiyyin. (v. 1-2). Beirut: Dar al-Kutub al-İlmiyyah.

Al-Alusi, Ş. M. (1415). Ruh al-Maani fi Tafsir al-Quran al-Azim wa Saba al-Masani. Beirut: Dar al-Kutub alïlmiyyah.

Al-Babani, İ. (n.d.). İdah al-Maknun fi al-Zayl Ala Keshf al-Zunnun. Beirut: Dar İhya alTuras al-Arabi.

Al Bukai, B. (n.d.). Nazm al-Durar fi Tanasub al-Ayat wa al-Suvar. Qairo: Dar al-Kitab alİslami.

Al Dahabi, Ş. (1992). al-Kashif fi Marifah man lahu Rivayat fi al-Kutub al-Sittah. Jeddah: Dar al-Qilblah li al-Sakafah al-İslamiyyah.

Al-Dahabi, Ş. (1993). Tarikh al-İslam ve wa Vafayat al-Mashahir wa al-Alam. (1. ed, v. 928). Beirut: Dar al-Garb al-İslami.

Al-Dahabi, Ş. (1993). Tarikh al-İslam ve wa Vafayat al-Mashahir wa al-Alam. (1. ed, v. 928). Dar al-Garb al-İslami.

Al-Farisi, A. (1989). al-Muntahab Mina al-Siyak li Tarikh Nisabur. Beirut: Dar al-Kutub alİlmiyyah.

Al-Firuzabadi, M. M. (2005). al-Kamus al-Muhit. Beirut: Muassasa al-Risalah.

Al-Hamawi, Y. (1977). Mucam al-Buldan. (v. 1-5). Beirut: Dar al-Sadr.

Al-Hilli, H. (n.d.). Kitab al-Manakib al-Mazyadiyyah fi Ahbar al-Muluk al-Esadiyyah. Amman: Maktaba al-Risala al-Hadisah.

Al-Husayni, S. A. (1933). Ahbar al-Dawlat al-Seljukiyyah. Lahor: University of Pencab. 
Al-Isfahani, İ. (1973a). Harida al-Kasr wa Carida al-Asr. (v. 4/2). Iraq: Muduriyyah alSakafa al-Ammah.

Al-Isfahani, İ. (1973b). Harida al-Kasr wa Carida al-Asr. (v. 4/1). Matbaat al-Macmaa alIraki.

Al-Ijli, A. (1985). al-Sikkatt. Medina: Maktaba al-Dar.

Al-İsbahani, A. (1998). Marifa al-Sahaba. Riyad: Dar al-Vatan li al-Nashr.

Al-Khorasani, M. M. (1390). Ravdat al-Cannat. Tahran: al-Haydariyyah.

Al-Masudi. (n.d.). al-Tenbih wa al-İshraf. Qairo: Dar al-Savi.

Al-Mizzi, Y. (1980). Tahzib al-Kamal fi Esma al-Rical. Beirut: Muassasa al-Risale.

Al-Qatii, A. (4112). Marasid al-İttila Ala Esma al-Emkina wa al-Buka. (v. 1-3). Beirut: Dar al-Cayl.

Al-Rudrawari. (2001). Zayl Kitab Tacarib al-Umam. Tahran: Dar al-Surush li al-Tabaa wa al-Nashr.

Al-Safadi,(2000). Kitab al-Vafi bi al-Vafayat. (1. ed, v. 1-21). Beirut: Dar İhya al-Turas alArabi.

Al Semani. (1962). al-Ensab. Haydarabad: Dairat al-Maarif al-Osmaniyah.

Al-Semani. (1988). al-Ensab. Beirut: Dar al-Cinan.

Al-Subki. (1413). Tabakat al-Shaiiyyah al-Kubra. Hicr li al-Tabaa wa al-Nashr wa alTavzi.

Al-Suyuti. (n.d.). Lub al-Lubab fi Tahrir al-Ensâb. Beirut: Dar al-Sadr.

Al-Tabari. (1968). Tarikh al-Rusul wa al-Muluk. Qairo: Dar al-Maarif.

Al-Zabidi, M. (2001). Tac al-Urus Min Cavahir al-Kamus (v. 34). Kuwait: Dar al-Hidayah.

Al-Zirikli, H. (1085). al-Alam (v. 1). Beirut: Dar al-İlim li al-Malayin.

Bahshal al-Wasiti. (1406). Tarikh Wasit. Beirut: Alam al-Kutub.

Burhanuddin al-Harezmi. (n.d.). al-Magrib. Dar al-Kitab al-Arabi

Hays Bays. (1974). Divan Emir Shabuddin Abul Favaris Hays Bays. Baghdad: Dar alHurriyah li al-Tabâa.

Ibn Abul Hayja. (1993). Tarikh İbn Abul Hayca. Riyad al-Salihin.

Ibn al-Adim, K. (n.d.). Bughya al-Talab fi Tarikh Haleb (v. 1). Beirut: Dar al-Fikir.

Ibn al-Athir. (n.d.-b). İslam Tarihi el Kamil fi't-Tarih Tercümesi. v. 7,8,9 (A. Özaydın, Transl.). İstanbul: Bahar Yayınları.

Ibn al-Athir. (1987). al-Kamil fi al-Tarikh (v. 8). Beirut: Dar al-Kitab al-Arabi.

Ibn al Athir. (1994). Usd al-Gabah fi Marifa al-Sahaba. Dar al-Kutub al-İlmiyyah.

Ibn Battuta. (2000). İbn Batttûta Seyahatnamesi (A. S. Aykut, Transl.). İstanbul: Yap1

Kredi Yayınlar1.

Ibn al-Fakih. (1996). al-Buldan. Beirut: Alam al-Kitab.

Ibn al-Fuwati. (1963). Talhis Macam al-Adab fi Mucam al-Alkab. (v. 4/2). Damascus: alMatbaat al-Hashimiyyah.

Ibn al-Fuwati. (2003). al-Havadis al-Camia wa Tacarib al-Nafia fi Mia al-Tasia. Beirut: Dar al-Kutub al-İlmiyyah.

Ibn al-Fuwati, K. (1416). Macma al-Adab fi Mucam al-Alkab. (v. 2-5). Tahran: Muasasa alTabaa wa al-Nashr.

Ibn Hajar al-Asqalani. (1326). Tazhib al-Tazhib. Beirut: Matbaat Daira al-Maarif alNizamiyah.

Ibn Hajar al-Asqalani. (1415). al-İsabe fi Tamyiz al-Sahaba. Beirut: Dar al-Kutub alİlmiyyah.

Ibn Hajar al-Asqalani. (2002). Lisan al-Mizan. Beirut: Maktaba al-Matbuat al-İslamiyyah.

Ibn Hallikan. (1977). Vafayat al-Ayan wa Enba al-Ebna al-Zaman. (v. 1-4). Beirut: Dar alSadr.

Ibn Hurdazbih. (1889). al-Masalik wa al-. Leiden: Beril Printing House. 
Ibn al-Jawzi. (1992). al-Muntazam fi al-Tarikh al-Muluk wa al-Umam. (1. ed, v. 15-17). Beirut: Dar al-Kutub al-illmiyah.

Ibn al-Jawzi, Sibt. (2013). Mirat al-Zaman fi Tarikh al-Ayan (1. ed, v. 1-21). Damascus: Dar al-Risala al-Alemiye.

Ibn Kathir. (1987). al-Bidayah wa al-Nihayah (1. ed, v. 15-16). İmbaba: Dar al-Hicr.

Ibn Kathir (2004). Tabakat al-Shafiiyun. (v. 1). Beirut: Dar al-Madar al-İslmai.

Ibn Khaldun. (2000a). Tarikhu İbn Haldun (v. 3-5). Beirut: Dar al-Fikir.

Ibn Makula. (1990). al-İkmal fî Raf al-İrtiyab an al-Mutalif wa al-Muhtalif fi al Esma wa alKuna wa al-Ensab. Beirut: Dar al-Kutub al-İlmiyah.

Ibn al-Mustawfi. (1980). Tarikh Erbil (v. 1-2). Iraq: Dar al-Raşid li al-Nashr.

Ibn al-Sai. (1934). Cami al-Muhtasar fi Unvan al-Tavarikh wa Uyun al-Siyar. (v. 9). Baghdad: Matbaat al-Suryaniyyah al-Kasulikiyyah.

Ibn Taghribardi. (1935). al-Nucum al-Zahirah fi Muluk al-Misır wa al-Qairo (v. 4-5). Qairo: Dar al-Kutub al-Misriyyah.

Ibn Unbe. (1961). Umda al-Talib (M. al Talkani, Transl.; 2. ed). Manshurat al-Matbaat alHayderiyyah.

Jawad, M. (1973). Cavan al-Kabila al-Kurdiyyah al-Mansiyyah wa Meshahir alJawaniyyin. Baghdad: Matbaat al-Macma al-Ami al-Kurdi.

Katip Chelebi. (1941). Kaşf al-Zunnun an Esma al-Kutub wa al-Funun (v. 2). Dar al-İhya al-Turas al-Arabi.

Keleş, N. (2014). Şeddâdîler Devleti Tarihi (951-1199). Mimar Sinan Fine Arts University, Social Sciences Institute, Unpulished Doctorate Thesis.

Maqrizi, T. A. (1997). al-Suluk li Maarifa Duval al-Muluk. Beirut: Dar al-Kutub alİlmiyyah.

Merçil, E. (1992). Besâsîrî. DİA (v. 5, p: 528-529). İstanbul: TDV.

Minorsky, V. (1988). Kürtler. Köln: Weşanên Halepçe.

Mohammed Emin Zeki. (1939). Hulasa Tarikh Kurd wa Kurdistan min Akdam al-Asr alTarikh Hatta al-An (M. A. Avni, Transl.). Egypt: Matbaat al Saadah.

Mohammed Emin Zeki. (1948). Tarikh al-Duval wa al-Emirates al-Kurdiyyah fi Ahd alİslamiyyah. Matbaat al-Saadah.

Varrām b. Abu Firas. (2013). Tenbih al-Havatir wa Nuzhat an Navazir (v. 1-3). Iraq: alAtabat al-Husayniyyah al-Mukaddasah.

Yaz, A. (2019). Mervânî Hükümdarı Nasrüddevle Ahmed. Ankara: Akademisyen Kitabevi.

Yıldız, H. D. (1988). Abbâsîler. DİA (v. 1, p: 49-56). Ankara: TDV.

Zarar, S. T. (n.d.). al-Kabail wa al-Zamam al-Kabilah al-Kurdiyyah fi Asr al-Wasit. Sulaimaniyah: Muassasa al-Mukiryani. 